\title{
DECONTAMINATION PROCESSES FOR WASTE GLASS CANISTERS
}

\author{
W. NEVYN RANKIN
}

\section{TIS FILF \\ RECORL}

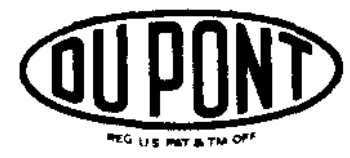

E. I. du Pont de Nemours \& Co. Savannah River Laboratory

Aiken, SC 29808 


\section{DISCLAIMER}

This report was prepared bv E. I. du Pont de Nemours and Company (Du Pont) for the United States Department of Energy under Contract DE-ACO9-76SR00001 and is an account of work performed under that Contract. Neither the United States, the United States Department of Energy nor Du Pont, nor any of their emplovees, makes any warranty, express or implied, or assumes any legal liability or responsibility for the accuracy, completeness, or usefulness of any information, apparatus, product, or process disclosed herein, or represents that its use will not infringe privately owned rights. Reference herein to any specific commerical product, process, or service by trade name, mark, manufacturer, or otherwise does not necessarily constitute or imply endorsement, recommendation, or favoring of same by Du Pont or by the United States Government or any agency thereof. The views and opinions of author's expressed herein do not necessarily state or reflect those of the United States Government or any agency thereof.

Printed in the United States of America

Avallable from

National Technical Information Service

U. S. Department of Commerce

5285 Port Royal Aoad

Springfield, Virginia 22161

Price: Printed Copy A03; Microfiche A01 
DP.1574

Distribution Category: UC-70

\title{
DECONTAMINATION PROCESSES
} FOR WASTE GLASS CANISTERS

\author{
W. NEVYN RANKIN
}

Approved by

L. M. Papouchado, Research Manager

Chemical Technology Division

Publication Date: June 1981

Issued by E. I. du Pont de Nemours \& Co. Savannah River Laboratory

Aiken, SC 29808 
The process which will be used to decontaminate waste glass canisters at the Savannah River Plant consists of:

- Decontamination (slurry blasting)

- Rinse (high-pressure water)

- Spot decontamination (high-pressure water plus slurry)

No additional waste will be produced by this process because glass frit used in decontamination will be mixed with the radioactive waste and fed into the glass melter.

Decontamination of waste glass canisters with chemical and abrasive blasting techniques was investigated. The ability of a chemical technique with $\mathrm{HNO}_{3}-\mathrm{HF}$ and $\mathrm{H}_{2} \mathrm{C}_{2} \mathrm{O}_{4}$ to remove baked-on contamination was demonstrated. A correlation between oxide removal and decontamination was observed. Oxide removal and, thus, decontamination by abrasive blasting techniques with glass frit as the abrasive was proposed and demonstrated. 


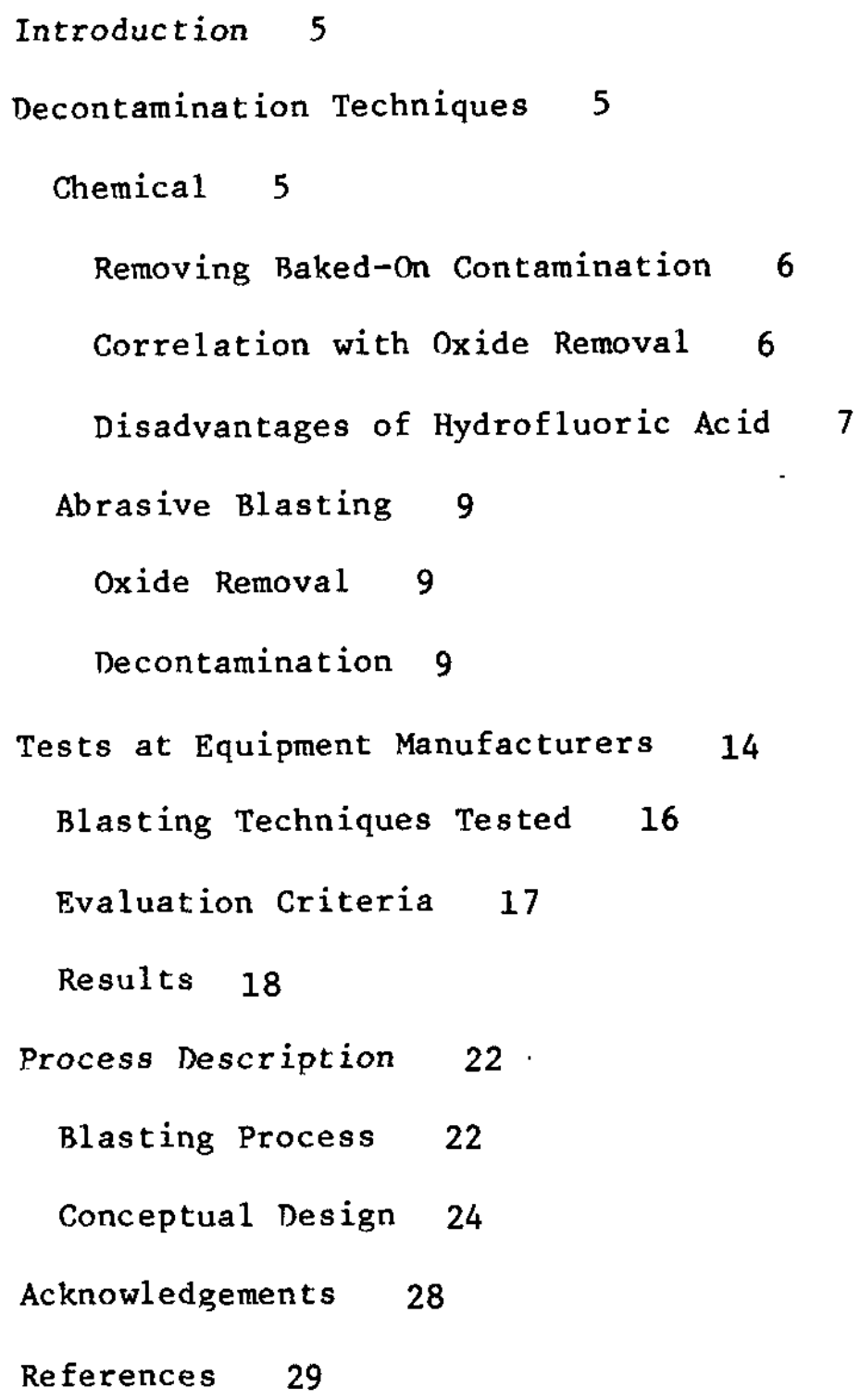




\section{INTRODUCTION}

The Savannah River Plant (SRP), operated for the U.S. Department of Energy by the Du Pont Company, has produced special nuclear materials for both defense and peaceful applications since 1953. Production of these materials has generated $\sim 25$ million gallons of high-level liquid radioactive waste. Methods to immobilize this waste for long-term storage are currently being developed at Savannah River Laboratory.

The present reference process for immobilization of SRP waste consists of immobilizing the waste in borosilicate glass. The liquid waste is mixed with glass frit, heated to $1150^{\circ} \mathrm{C}$ in a joule-heated ceramic melter at which temperature the waste is dissolved in the molten glass. The molten product is then poured into Type 304L stainless steel canisters and allowed to cool in air.

This paper describes the process developed to decontaminate the surface of the sealed canisters before removal from the processing facility. Decontamination of the canisters allows them to be removed from the processing facility and emplaced in interim storage without spreading contamination.

\section{DECONTAMINATION TECHNIQUES}

\section{Chemical}

Chemical decontamination techniques are ideally suited to remote operations because of their simplicity. The canister is immersed in solutions which dissolve the contaminated outer portion of its surface. The canister is then rinsed to remove dissolved contamination.

A technique which includes the use of $\mathrm{HNO}_{3}-\mathrm{HF}$ and $\mathrm{H}_{2} \mathrm{C}_{2} \mathrm{O}_{4}$ was previously developed (Table 1) at the Savannah River Laboratory (SRL) to decontaminate stainless steel canisters. $\mathrm{HNO}_{3}-\mathrm{HF}$ was selected to remove the oxide film from the stainless steel. These acids are widely used as a standard practice for cleaning and descaling stainless steel parts. $\mathrm{H}_{2} \mathrm{C}_{2} \mathrm{O}_{4}$ is a complexing agent that has been used for decontamination for years. ${ }^{2}$ 
TABLE 1

Chemical Decontamination Process

$\begin{array}{lllll}\text { Step } & \text { Solution } & \text { Concentration } & \text { Temperature } & \text { Time, } \\ \text { Etch } & \mathrm{HNO}_{3}-\mathrm{HF} & 3.9 \mathrm{M} \mathrm{HNO}_{3}-0.4 \mathrm{M} \mathrm{HF} & \text { Room temperature } & 1 \\ \text { Rinse } & \mathrm{H}_{2} \mathrm{O} & & \text { Room temperature } & \\ \text { Clean } & \mathrm{H}_{2} \mathrm{C}_{2} \mathrm{O}_{4} & 100 \mathrm{~g} / \mathrm{L} & \text { Boiling } & 1 \\ \text { Rinse } & \mathrm{H}_{2} \mathrm{O} & & \text { Room temperature } & \\ \text { Etch } & \mathrm{HNO}_{3}-\mathrm{HF} & 3.9 \mathrm{M} \mathrm{HNO}{ }_{3}-0.4 \mathrm{M} \mathrm{HF} & \text { Room temperature } & 1 \\ \text { Rinse } & \mathrm{H}_{2} \mathrm{O} & & \text { Room temperature } & \\ \text { Clean } & \mathrm{H}_{2} \mathrm{C}{ }_{2} \mathrm{O}_{4} & 100 \mathrm{~g} / \mathrm{L} & \text { Boiling } & 1 \\ \text { Rinse } & \mathrm{H}_{2} \mathrm{O} & & \text { Room temperature } & \end{array}$

\section{Removing Baked-On Contamination}

The ability of the $\mathrm{HNO}_{3}-\mathrm{HF}$ and $\mathrm{H}_{2} \mathrm{C}_{2} \mathrm{O}_{4}$ technique to remove baked-on contamination from Type $304 \mathrm{~L}$ stainless steel specimens was evaluated. Specimens used in the test were one-in. ${ }^{2}$ pieces of Type $304 \mathrm{~L}$ stainless steel with No. 1 surface finishes (hot-rolled, pickled, and annealed). 3 One face of some specimens was wet ground with 240-grit emery paper to evaluate the effect of better surface finishes (simulated No. 2B). ${ }^{3}$ Specimens were contaminated up to $300,000 \mathrm{dis}(\alpha) /\left(\min \mathrm{dm}^{2}\right)$ by placing one drop of a plutonium nitrate solution in the center of one face of each specimen. The specimens were then heated for $16 \mathrm{hr}$ at $600^{\circ} \mathrm{C}$ in air to produce an oxide film similar to the film expected on the outside of canisters filled with waste glass. Specimens were carried through the chemical decontamination process (Table 1); then they were smeared to determine the remaining amount of contamination.

\section{Correlation With Oxide Removal}

Results with oxide removal in the chemical decontamination tests (Table 2) show that consistent decontamination was not achieved with specimens which had No. 1 surface finishes. The amount of contamination remaining on the surfaces of specimens was proportional to the amount of oxide remaining on the surfaces. Specimens with simulated No. $2 B$ surface finishes were consistently decontaminated to $10 \mathrm{dis}(\alpha) /\left(\min \mathrm{dm}^{2}\right)$. In all of these specimens, all of the oxide was removed from the surfaces. 
TABLE 2

Results of Chemical Decont amination Tests

\begin{tabular}{|c|c|c|c|}
\hline $\begin{array}{l}\text { Surface } \\
\text { Einish No. }\end{array}$ & $\begin{array}{l}\text { Contamination } \\
\text { Start, } \\
\text { dis } /\left(\min \cdot \mathrm{dm}^{2}\right)\end{array}$ & $\begin{array}{l}\text { Contamination } \\
\text { Finish, } \\
\left.\text { dis/(min } \mathrm{dm}^{2}\right)\end{array}$ & Appearance \\
\hline 1 & 300,000 & 15,000 & Brown oxide \\
\hline 1 & 300,000 & 120 & Brown oxide \\
\hline 1 & 200,000 & 400 & Some brown oxide \\
\hline 1 & 200,000 & 30 & Clean \\
\hline 2B（simulated) & 200,000 & $<10$ & Clean \\
\hline 2B (simulated) & 200,000 & $<10$ & Clean \\
\hline 2B (simulated) & 200,000 & $<10$ & Clean \\
\hline
\end{tabular}

The difference in appearance of No. 1 and simulated No. 2B surface finishes after each step in the decontamination process is shown with a specimen that was wet ground on $240 \mathrm{grit}$ abrasive paper to simulate a No. 2B surface finish (Figure 1). The ground area in the center of the specimen could be easily seen. The remaining outer portion of the specimen was the original No. 1 surface. This portion of the specimen was not contacted during grinding because the edges of the specimen had been rounded when the specimen was sheared from the plate.

This specimen was photographed and surveyed after each step of decontamination. The oxide was removed from the simulated No. $2 B$ surface finish portion of the specimen by the first $\mathrm{HNO}_{3}-\mathrm{HF}$ etch. Oxide still remained on parts of the No. 1 surface finish portion of the sample after the specimen had been through the entire decontamination process.

\section{Disadvantages of Hydrofluoric Acid}

There are disadvantages to using hydrofluoric acid in a remote facility. Process vessels and exhaust ducts would have to be fabricated from more expensive, corrosion-resistant materials. Hydrofluoric acid vapor corrosion throughout the entire cell block is possible. Even the glass windows of the cells could be etched by the hydrofluoric acid. Disposal of hydrofluoric acidcontaining wastes would also be difficult. 
Contaminated, Oxidized Specimen Before Decontamination

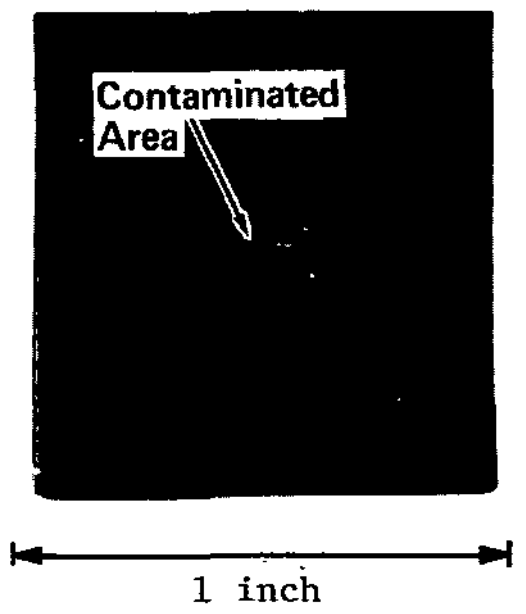

$200,000 \mathrm{dis}(\alpha) /\left(\min \mathrm{dm}^{2}\right)$

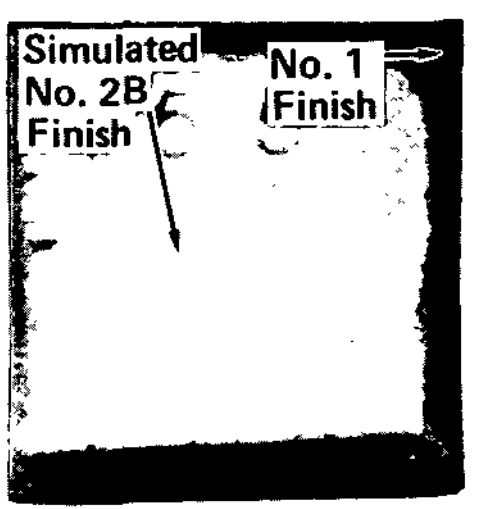

$1 \mathrm{hr}$ in $\mathrm{HNO}_{3}-\mathrm{HF}$ $30 \mathrm{dis}(\alpha) /\left(\min \mathrm{dm}^{2}\right)$

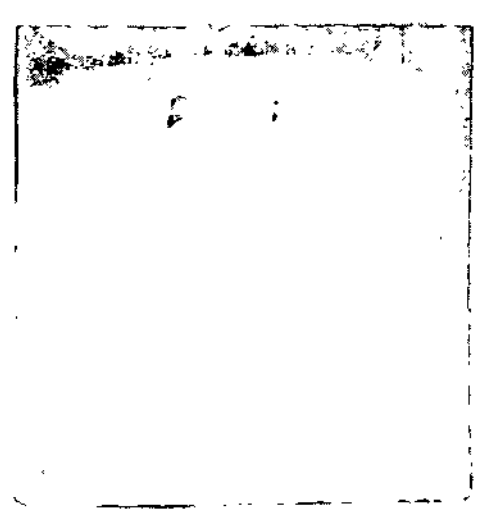

$$
\begin{gathered}
1 \mathrm{hr} \text { in } \mathrm{HNO}_{3}-\mathrm{HF} \\
1 \mathrm{hr} \mathrm{H}_{2} \mathrm{C}_{2} \mathrm{O}_{4} \\
0 \mathrm{dis}(\alpha) /\left(\text { min } \mathrm{dm}^{2}\right)
\end{gathered}
$$

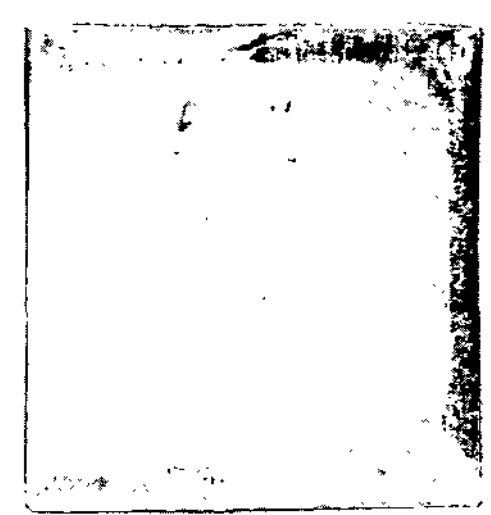

$2 \mathrm{hr}$ in $\mathrm{HNO}_{3}-\mathrm{HF}$

$1 \mathrm{hr}$ in $\mathrm{H}_{2} \mathrm{C}_{2} \mathrm{O}_{4}$

$0 \operatorname{dis}(\alpha) /\left(\min \mathrm{dm}^{2}\right)$

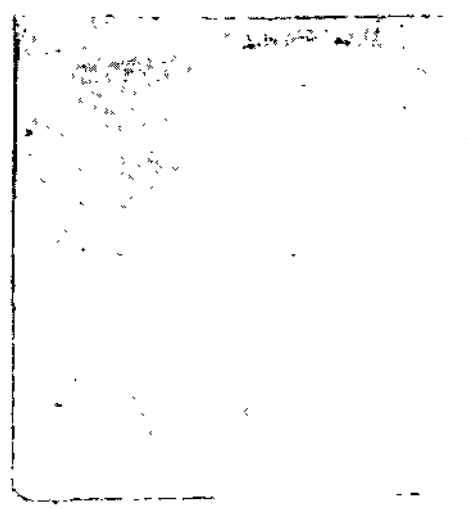

2 hr in $\mathrm{HNO}_{3}-\mathrm{HF}$

$2 \mathrm{hr}$ in $\mathrm{H}_{2} \mathrm{C}_{2} \mathrm{O}_{4}$

$0 \operatorname{dis}(\alpha) /\left(\min \mathrm{dm}^{2}\right)$

FIGURE 1. Appearance of Type 304L Stainless Steel During Chemical Decontamination 


\section{Abrasive Blasting Techniques}

Abrasive blasting techniques were investigated as an alternative to the $\mathrm{HNO}_{3}-\mathrm{HF}$ etch during decontamination because 1) no hydrofluoric acid would be necessary; 2) the cost of the entire waste form fabrication facility could be reduced because the building could be smaller (room for acid-processing equipment would not be needed), and less expensive materials of construction could be used because resistance to hydrofluoric acid would not be required (i.e., ventilation ducts); and 3 ) decontamination could be effected with the generation of no additional waste if the glass frit that is needed for waste vitrification would be used as the abrasive for blasting.

\section{Oxide Removal}

The ability of several abrasive blasting techniques to remove an oxide film from Type 304L stainless steel was demonstrated with several abrasives, including the glass frit which will be used in waste glass production. Specimens were blasted with dry abrasive, wet abrasive, and high-pressure water. Specimens $1 \times 3$ in. were sawed from a 1/4-in.-thick plate with a No, 1 surface finish or sheared from a 60-mil-thick plate with a No. 2B surface finish. ${ }^{3}$ They were oxidized by heating in air for $16 \mathrm{hr}$ at $600^{\circ} \mathrm{C}$. These conditions were an estimate of the temperature that the outside of a canister would experience as it was filled with molten waste glass. In all tests, the nozzle was held 6 in. from the specimens at an angle of $45^{\circ}$ with the surface of the specimens. Half of the specimens was covered during blasting so that part of the original surface would be retained for comparison. The results of these rests are given in Table 3. These results show that abrasive blasting, with the glass frit as the abrasive, is very effective for removing oxide from Type 304L stainless steel. Blasting with both dry and wet abrasive Frit 411 for only $5 \mathrm{sec}$ removed the oxide. The change in specimen thickness was less than $1 \mathrm{mil}$. Neither technique was dependent on the surface finishes of the specimens before the specimen was oxidized. High-pressure water blasting (no abrasive) failed to remove any oxide in $30 \mathrm{sec}$.

\section{Decont amination}

The ability of abrasive blasting techniques with glass frit to remove baked-on radioactive contamination from the surface of Type 304L stainless steel was demonstrated. Four blasting techniques were used in these tests - dry abrasive blasting, dry abrasive blasting with water attachment, high-pressure water blasting, and high-pressure water blasting with abrasive. In all techniques with abrasive, Frit $211(-20+80$ mesh) was used (Table 4). For the dry-abrasive blasting technique, a simple, 
TABLE 3

Rosults of Oxide Renoval Test

Decont aminat ion

Technique

Dry-abrasive

Blasting
Abragive

Frit $411(-20+80$ mesh $)$

$\mathrm{Al}_{2} \mathrm{O}_{3}$ (180 mesh)

Glass Beads (100-170 mesh)

20-40
Wet-Abrasive Blaating**
Frit $411(-20+80$ mesh $)$
High-Pressure Water Blasting
None

1000
Results

Under all conditions, oxide $r$ tmoved in 5 sec.

Changes in dimension $11 \mathrm{mil}$.

Surface finish inversely proportional to grit size of abrasive and blasting pressure.

$C l e a n e d$ Nor. 1 and $2 B$ surfaces equally well.

Specimens cleaned with glass

beads had a brighter finish. Specimens cleaned with Frit 411 or Al 0 had a more mate finish. This difference was atcributed to greater "cutting action" of the particles with the more angular shape.

Under all conditions, oxide removed in 5 sec.

Change in dimension < 1 mil.

Cleaned Nos. I and 2B surfaces equally well.

Surface finish inversely proportional to blasting pressure.

Les 8 surf ace roughness was produced by wet-abrasive blasting with Frit 411 than by dry-abrasive blast ing with Frit 411 .

Blasting with water only, for $30 \mathrm{sec}$, did not appear to remove any oxide from the surface

* The equipment used for dry abrasive blasting was manufactured by the Vacu-Blast Corporation.

* The equipment used for wet abrasive blasting and high-pressure blasting was a Myers MC $10-12 \mathrm{M}$ Mobile Hydraulic Cleaner.

TABLE 4

Composition of Glass Prits

\begin{tabular}{|c|c|c|c|}
\hline Metal Oxide & $\frac{\text { Frit, }}{211}$ & $\frac{\%}{21}$ & 411 \\
\hline $\mathrm{SiO}_{2}$ & 58.3 & 52.5 & 58.3 \\
\hline $\mathrm{Na}_{2} \mathrm{O}$ & 20.6 & 18.5 & 12.5 \\
\hline $\mathrm{B}_{2} \mathrm{O}_{3}$ & 11.1 & 10.0 & 11.1 \\
\hline $\mathrm{TiO}_{2}$ & - & 10.0 & - \\
\hline $\mathrm{CaO}$ & 5.6 & 5.0 & 5.6 \\
\hline $\mathrm{Li}_{2} \mathrm{O}$ & 4.4 & 4.0 & 12.5 \\
\hline
\end{tabular}


inexpensive sandblast unit (Pauli and Griffin Model 10W super sand blast machine) was used. In some tests, dust was eliminated by attaching a water attachment to the blasting nozzle to introduce a small amount of water into the blast stream. For high-pressure blasting, a Myers MC 10-12M mobile hydraulic cleaner was used. No abrasive was used in high-pressure water blasting. In some tests with high-pressure water, abrasive was mixed with the water stream from a Myers water sand gun assembly. All blasting was done inside an approximate $9-\mathrm{ft}^{3}$ cask decontamination facility in the SRL High Level Caves (HLC) (Figure 2) which is used for decontaminating radioactive casks. It is designed with features that are standard for nuclear equipment to effectively contain airborne and liquid radioactive materials:

- Air is exhausted from the facility at $500 \mathrm{ft}^{3} / \mathrm{min}$ through high efficiency particulate air filters.

- The floor drain from the facility is connected to the highlevel drain.

A pair of locking pliers attached to a wooden "saw horse" was used to hold the specimen during testing. The hose from the blasting equipment was run through the door of the cask decontamination facility. Glove ports were used to operate the blast hose.

Two types of specimens were used in these tests (Figure 3):

Specimens with Baked-On Alpha Contamination

These specimens were 1- x 3-in. coupons of Type 304L stainless steel. Their surfaces were prepared the same way as the surfaces of specimens used for evaluating chemical decontamination procedures. ${ }^{3}$ The specimens were contaminated with up to $400,000 \mathrm{dis}(\alpha) /\left(\min \mathrm{dm}^{2}\right)$; then, they were heated for $16 \mathrm{hr}$ at $600^{\circ} \mathrm{C}$ to incorporate this contamination in an oxide film similar to that expected on a canister containing waste glass.

Specimens with Alpha, Beta, and Gamma Contamination

These specimens were 3/8- x 3-in. coupons of Type 304L stainless steel that were suspended inside the vapor space of the melter for up to $20 \mathrm{hr}$ while the melter was producing waste glass at $1200^{\circ} \mathrm{C}$. The melter was being fed $66 \mathrm{~g} / \mathrm{hr}$ of 65 wt $\%$ Frit 21 and 35 wt \% sludge from Tank 13. 


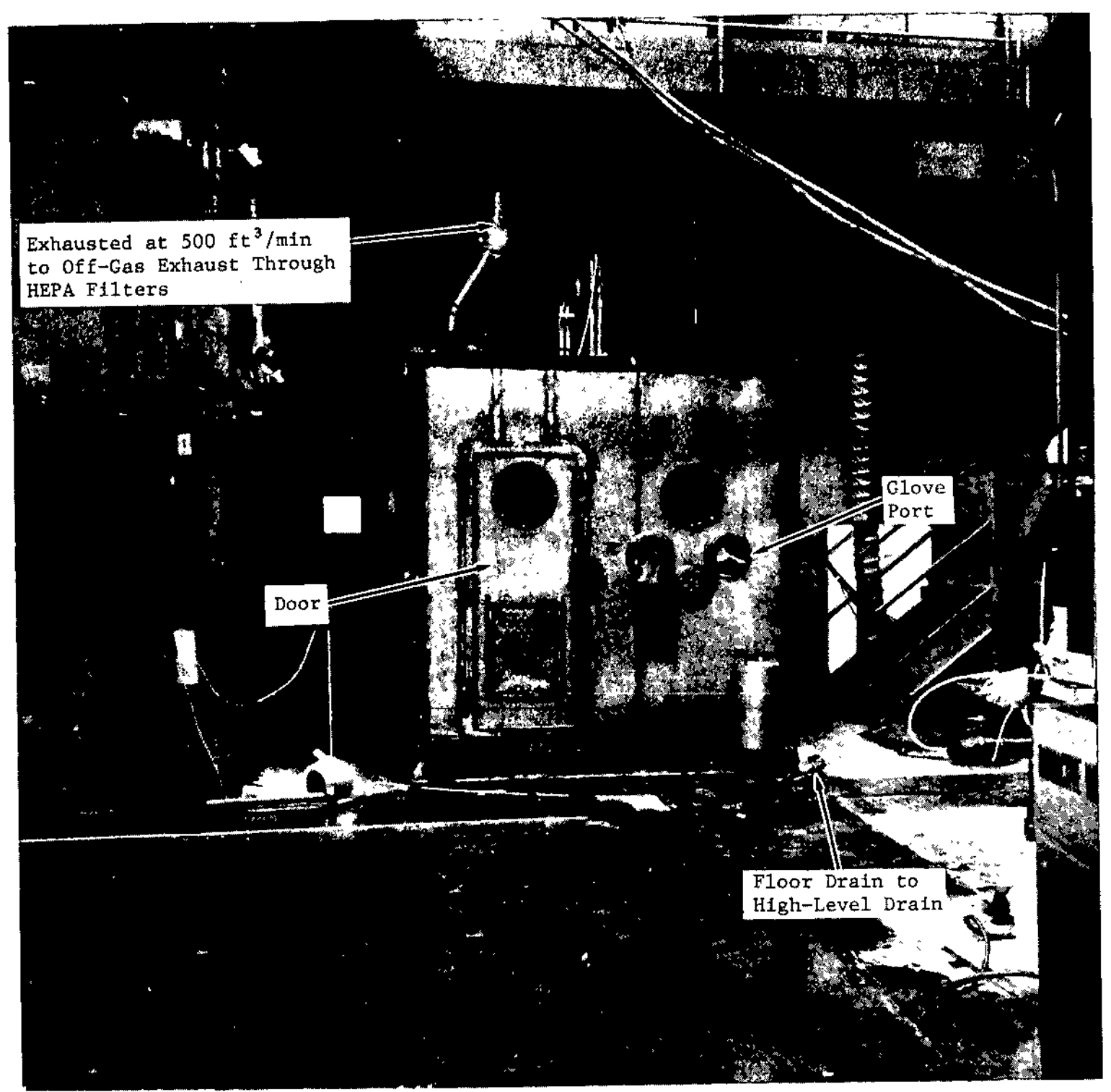

FIGURE 2. HLC Decontamination Facility 


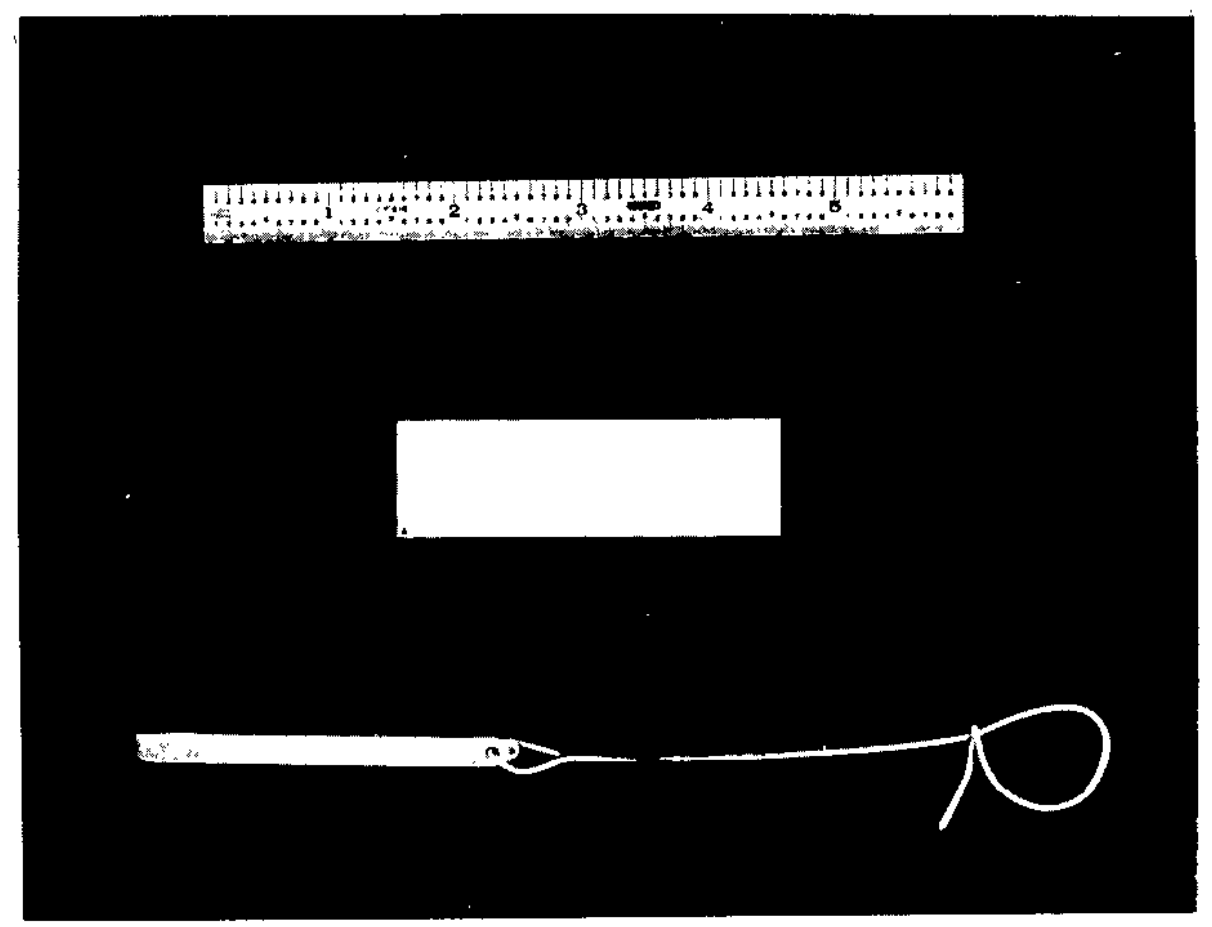

FIGURE 3. Test Specimens 
These specimens were both oxidized and covered with a wite film. Smearable contamination was $9 \times 10^{5} \mathrm{dis} / \mathrm{min}$ alpha, beta, and garma. Gamma scan analyses of acid solutions used to remove this material showed that it was primarily ${ }^{137} \mathrm{Cs}$.

The results of the tests (Table 5) showed that any of the blasting techniques with Frit $211(-20+80$ mesh) removed all smearable contamination from the Type $304 \mathrm{~L}$ stainless steel specimens. Blasting with $1000 \mathrm{psi}$ water only reduced but did not eliminate the amount of smearable contamination.

The amount of glass frit and water necessary to decontaminate an entire canister was determined from the amounts used in these laboratory-scale tests. These predictions showed that the amount of frit consumed by each process tested (Table 5) was well below the amount of frit in a canister of waste glass $(>20001 \mathrm{~b})$. The amount of water required was within reason for disposal purposes according to discussions with SRP and Du Pont Engineering Department personnel.

Equipment to contain radioactivity removed from canisters by abrasive blasting techniques was designed from standard concepts for the nuclear industry. Both airborne and liquid radioactivity was successfully contained by the blast chamber in the decontamination facility.

\section{TESTS AT EQUIPMENT MANUFACTURERS}

The applicability of several abrasive blasting techniques to canister decontamination was investigated in large-scale tests at equipment manufacturers. Test specimens were $12-$ in. ${ }^{2}$ plates. In the tests, half of the surfaces of the plates was masked to retain the original surface for comparison.

The procedure followed at the equipment manufacturers was to 1) discuss the usefulness of their process to our applicaton and 2) demonstrate the ability of the processes to remove oxidation from a 12-in. ${ }^{2}$ plate of Type 304L stainless steel. The abrasives used in the demonstrations of the first three processes were $-20+80$ and -80 mesh Frit 411 (Table 4). 
TABLE 5

Results of Tests in Decontamination Facility

\begin{tabular}{|c|c|c|c|c|c|c|c|}
\hline \multirow[b]{2}{*}{$\begin{array}{l}\text { Decontamination } \\
\text { Technique }\end{array}$} & \multicolumn{6}{|c|}{ Decont aminat ion Leve 1} & \multirow[b]{2}{*}{$\begin{array}{l}\text { Projected } \\
\text { Consumpt ion } \\
\text { Rate/Canister }\end{array}$} \\
\hline & $\begin{array}{l}\text { Be fore } \\
\text { Baked- } \\
\text { On, } \\
\alpha \text { dis/min }\end{array}$ & $\begin{array}{l}\text { Melter } \\
\alpha \text { dis/min }\end{array}$ & $B-Y c / m^{*}$ & $\begin{array}{l}\text { After } \\
\text { Baked- } \\
\text { On, } \\
\alpha \text { dis/min }\end{array}$ & $\begin{array}{l}\text { Melter } \\
\text { adis/min }\end{array}$ & $\bar{B}-\gamma \mathrm{c} / \mathrm{m}$ & \\
\hline $\begin{array}{l}\text { Dry-Abrasive } \\
\text { Blasting }\end{array}$ & $\begin{array}{c}200,000 \\
\text { to } \\
400,000\end{array}$ & 4,000 & $9 \times 10^{5}$ & Background** & Background** & Background** & 500 lb frit \\
\hline $\begin{array}{l}\text { Dry-Abrasive } \\
\text { Blast ing } \\
\text { With } \mathrm{H}_{2} \mathrm{O} \\
\text { Att achment }\end{array}$ & $\begin{array}{c}200,000 \\
t 0 \\
400,000\end{array}$ & 4,000 & $9 \times 10^{5}$ & Background & Background & Background & $\begin{array}{l}500 \mathrm{lb} \text { frit } \\
200 \text { gal } \mathrm{H}_{2} \mathrm{O}\end{array}$ \\
\hline $\begin{array}{l}\text { High-Pressure } \\
\mathrm{H}_{2} \mathrm{O} \text { Blasting } \\
\left(\text { (OOOO psi) }^{\circ}\right.\end{array}$ & $\begin{array}{c}200,000 \\
t 0 \\
400,000\end{array}$ & 4,000 & $9 \times 10^{5}$ & Up to 3690 & Up to 354 & Up to 68,000 & 50,000 gal $\mathrm{H}_{2} \mathrm{O}$ \\
\hline $\begin{array}{l}\text { High-Pressure } \\
\mathrm{H}_{2} \mathrm{O} \text { Blasting } \\
\left(\text { IOO00 psi) }^{2}\right.\end{array}$ & $\begin{array}{c}200,000 \\
\text { to } \\
400,000\end{array}$ & 4,000 & $9 \times 10^{5}$ & Background & Background & Background & $\begin{array}{l}3500 \text { gal } \mathrm{H}_{2} \mathrm{O} \\
500 \mathrm{lb} \text { frit }\end{array}$ \\
\hline
\end{tabular}

* One $\mathrm{mR} / \mathrm{hr}=4000 \mathrm{c} / \mathrm{m}$.

** The smears from these specimens were counted in specially shielded counters where the background is $<4$ counts/24 hours alpha and $<0.2$ counts/min B-Y from ${ }^{137} \mathrm{Cs}$. 


\section{Blasting Techniques Tested}

The techniques investigated are discussed briefly in the following paragraphs:

Dry

Abrasive particles were propelled by compressed air at pressures of 20 and $40 \mathrm{psi}$ against the surfaces of the plates being decontaminated. for all tests, $400 \mathrm{ft}^{3} / \mathrm{min}$ of air was circulatęd through the blast chamber, and the abrasive was fed through a 1/4-in. nozzle at a distance from 6 to 18 in. and at blast angles of 30,45 , and $90^{\circ}$. After the plates were blasted, they were blown with compressed air for cleaning.

- Slurry

A slurry of abrasive particles in water was propelled by compressed air against the surface being decontaminated. These tests were carried out with a Vacu-Blast slurry honing machine (Vacu-Blast Corp., Belmont, CA) which had a 3/8-in.-dia nozzle and a 3/16-in-dia air jet. The blast angle, frit size, and blast pressure were varied.

After the plates were blasted, they were rinsed with highpressure water at $2000 \mathrm{psi}$ by an Aqua-Dyne GE $150 \mathrm{high-pressure}$ pump. Approximately $7.2 \mathrm{gal} / \mathrm{min}$ was directed at the surfaces for $20 \mathrm{sec}$ with a $15^{\circ}$ fan nozzle 12 in. from the plates.

- High-Pressure Water Plus Frit

A frit and water slurry was incorporated with the highpressure water stream from an Aqua-Dyne GE 150 high-pressure pump (Aqua-Dyne Engineering, Inc., Houston, TX) and directed at the surfaces being cleaned. About $15 \mathrm{gal} / \mathrm{min}$ of water at $5000 \mathrm{psi}$ was directed at the plates for about $30 \mathrm{sec}$ through a 1/4-in, orifice of an Aqua-Dyne sand gun held about 12 in. from the plates. During this time, $2-1 / 2$ gal of a 20 vol \% slurry of water and -80 mesh Frit 411 was drawn into the blast stream by the venturi effect. 
- High-Pressure Water

High-pressure water blasting consists of blasting the surfaces of plates being cleaned with jets of high-pressure water, eliminating the need for abrasive. About $21 \mathrm{gal} / \mathrm{min}$ of water at up to 10,000 psi was supplied by an Aqua-Dyne GE 150 high-pressure pump. The water was passed through a $15^{\circ}$ fan nozzle located $1 / 2$ in. from the surfaces of the plates. The nozzle was moved at about $1.8 \mathrm{ft} / \mathrm{min}$ across the plates.

- Solid $\mathrm{CO}_{2}$ Pellet 4

Approximately $500 \mathrm{lb} / \mathrm{hr}$ of about 1/8-in.-dia $\mathrm{x}$ about

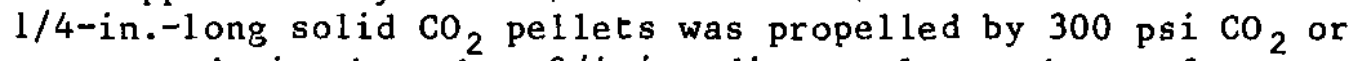
compressed air through a 3/4-in.-dia nozzle at the surfaces being decontaminated. The nozzle was held $4 \mathrm{in}$. from the plates at $90^{\circ}$.

\section{Evaluation Criteria}

After the tests, the plates were returned to SRP for evaluation. The criteria used in this evaluation are discussed in the following paragraphs:

- Oxide Removal

Plates were blasted until the oxide appeared to be completely removed. The cleaning rate (min/ft ${ }^{2}$ ) was determined.

- Consumption Rate

The amount of glass frit and/or water or $\mathrm{CO}_{2}$ needed to clean a canister was projected from the amount needed to clean the test specimen.

- Surface Finish Measurements

The surface finishes of the plates were measured with a "Surtronic 3" (Rank Taylor Hobson, Leichester, England). This instrument has a motor driven arm which pulls a small, sharp contact point across the surfaces of the places. The contact point is displaced as it passes over the minute hills and valleys of the surfaces. This movement is electrically measured and averaged. A direct reading meter shows the average deviation of the surface in microinches. 
- Surface Topography

Oblique lighting was used to examine and characterize the surface topography of the specimens on the metallograph.

- Surface Cleanness

Two techniques were used to determine surface cleanness: 1) The surfaces of the specimens were observed on the metallograph with polarized light. Frit particles trapped in topographical features showed as white areas. The volume of frit particles trapped in the surface topography of a canister was estimated.

2) Surface cleanness was evaluated by a modification of a simple wiping test. Immediately after the specimens were blasted, a piece of Minnesota Mining and Manufacturing Company's double-coated neoprene foam tape No. 4262 was pressed against the surfaces. The volume of loose frit particles per unit of surface area was determined by scanning electron microscopy and $x-r$ ay emission spectroscopy techniques with the low $x$-ray background $t$ ape as the specimen. This volume was projected to estimate the volume of loose frit that would remain on the surface of a canister.

- Nozzle Lifetime estimates.

Nozzle lifetime was predicted from the manufacturer's

\section{Results}

The results of the tests at equipment manufacturers are given in Table 6 and discussed in the following paragraphs. A considerable amount of dust occurred in dry blasting when the -80 mesh frit was used. No dust was observed for any blasting process when water was used. The concentration of airborne droplets of water was independent of the frit size.

- Oxide Removal

Dry frit, slurry, and high-pressure water plus frit blasting removed the oxide from the Type 304L stainless stee 1 plates at a rate fast enough to make these processes attractive for canister decontamination. Oxide removal by all of these techniques was rather insensitive to process variables. Highpressure water plus frit is the fastest process ( $1 \mathrm{~min} / \mathrm{ft}^{2}$ ) 
TABLE 6

Results of Evaluation of Plate Surfaces

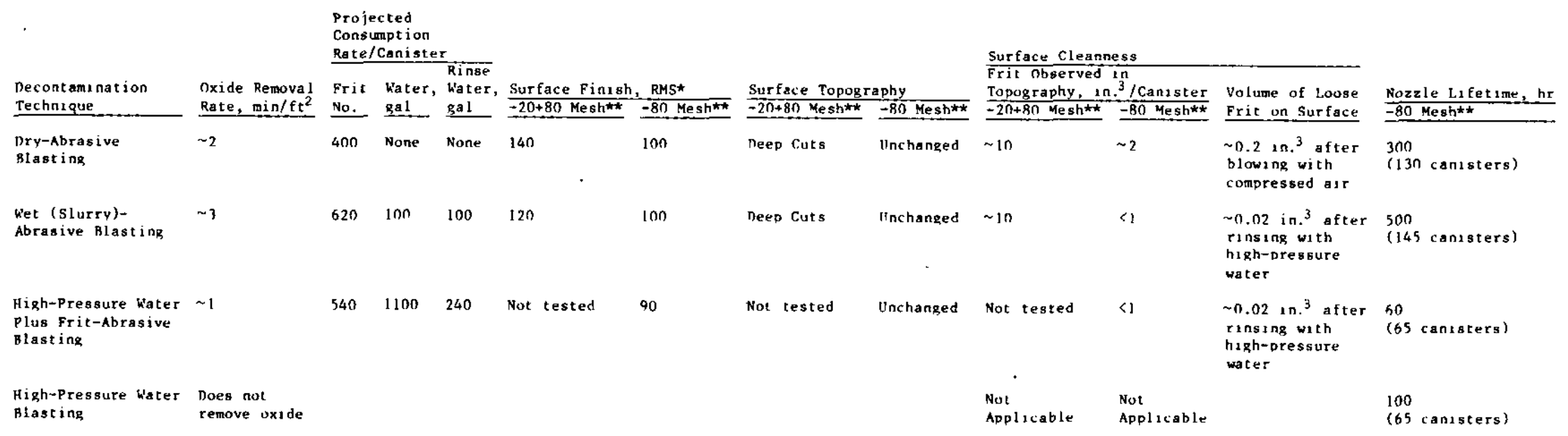

Solid $\mathrm{Cr}_{2}$ Pellet $\quad \sim 1440$

* Surface of plates before blasting 100 RMS. (RMS is the root-mean-square average deviation from the mean surface. A laver value indicates a rugher surface.)

** Fric 411 . 
because part of the energy of the $5000 \mathrm{psi}$ water was used in scouring the surfaces of the plates with the frit particles. Oxide was not removed by blasting with high-pressure water. These results confirmed the results of oxide removal tests at SRL, which indicated that high-pressure water alone would not remove baked-on contamination from Type 304L stainless steel. Solid $\mathrm{CO}_{2}$ pellet blasting removed the oxide from Type 304L stainless steel, but the removal rate ( $1440 \mathrm{~min} / \mathrm{ft}^{2}$ ) was so that this process cannot be used for canister demontamination. However, the decontamination process can be used for applications where the contamination is not incorporated into an oxide film.

- Consumption Rate

The estimated amount of frit and water necessary to clean a canister with dry frit, slurry, and high-pressure water plus frit blasting is within reason for canister cleaning. In all cases, the amount of frit required is well below the approximate $2000 \mathrm{lb}$ of frit required for fabrication of a canister of waste glass.

Blasting with dry frit is the simplest process requiring only frit. Blasting with slurry requires more frit plus water for blasting and rinsing. Blasting with high-pressure water and with dry frit requires about the same amount of frit as blasting with slurry but with much more water.

- Surface Finishes

The surface finishes of the plates were dependent on the size of the frit used during the blasting with dry frit, slurry, or high-pressure water plus frit. The surface finishes were changed very little by either process with -80 mesh frit. The larger frit, $-20+80$ mesh, roughened the surfaces.

- Surface Topography

The correlation between the appearance of surface topography (Figure 4) and surface finish measurements was good. Irregularities on the surfaces of plates blasted with the smaller frit ( -80 mesh) were smaller than those that existed on the original hot-rolled, pickled surfaces of the plates. More surface irregularities occurred on plates blasted with $-20+30$ mesh frit than on plates blasted with -80 mesh frit. Surfaces blasted with the larger frit $(-20+30$ mesh) were covered with a series of small gulleys caused by the cutting and scouring action of the impacting frit particles. 


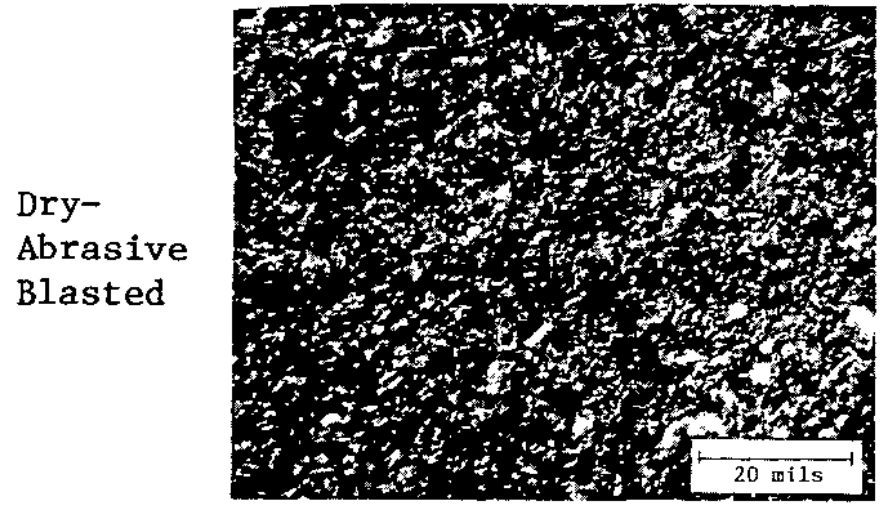

100-125 RMS

(

$N$

Wet

(Slurry)Abrasive Blasted
Surface Before Abrasive Blasting (ASTM No. 1 , Oxidized $16 \mathrm{hr}$ at $600^{\circ} \mathrm{C}$ )

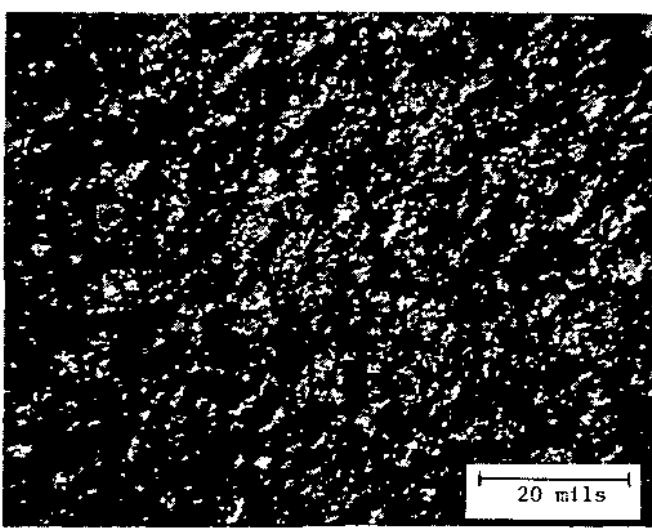

65-75 RMS

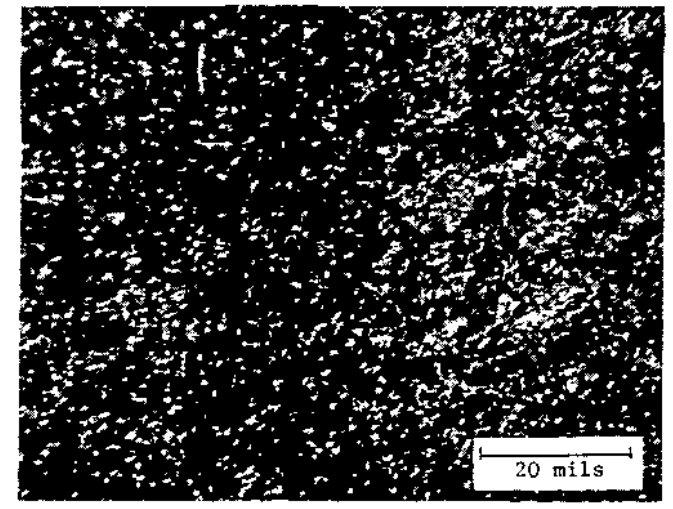

80-110 RMS

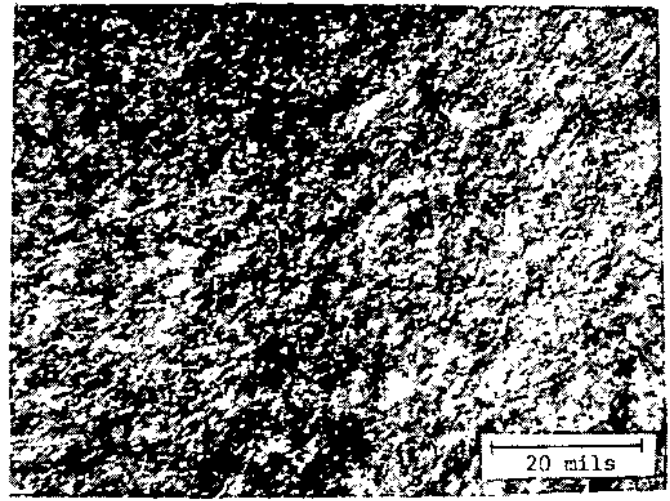

70-75 RMS

FIGURE 4. Surface of Abrasive Blasted Type 304L Stainless Steel 
- Frit observed in Topography

A small amount of frit particles was observed in the surface topography of the plates (Figure 5). This frit was mechanically wedged in relief features on the surfaces. The frit was not displaced by blowing the surfaces with compressed air after the surfaces were blasted with dry frit or rinsed with high-pressure water after blasting with slurry. The volume of frit in the surface topography is directly proportional to the surface roughness. The volume of frit in the valleys on the rougher surfaces produced by blasting with the larger frit $(-20+80$ mesh $)$ is projected to about 10 in. ${ }^{3}$ per canister. The projected volume of $\mathrm{frit}$ is $<1 \mathrm{in}^{3}$ on a canister with a smoother surface finish produced by blasting with the smaller frit ( -80 mesh).

- Volume of Loose Frit on Surfaces

A small amount of loose frit remained on the surfaces that had been blasted with either dry frit, slurry, or high-pressure water plus frit. A high-pressure water rinse was more effective in removing this material than in blowing the surfaces with compressed air.

- Nozzle Lifetime

The nozzle lifetime, after being used for blasting with dry frit, slurry, and high-pressure water plus slurry, is within reason for use in canister decontamination applications. The lifetime of nozzles used for blasting with high-pressure water plus frit is shorter than that of nozzles used for blasting with slurry or dry frit. Blasting with high-pressure water plus dry frit is a more powerful process and, therefore, wears out nozzles faster.

\section{PROCESS DESCRIPTION}

\section{Blasting Process}

The abrasive blasting process to be used to decontaminate SRP waste glass canisters consists of the following techniques with -80 mesh frit as the abrasive:

- Slurry for decontamination

- High-pressure water for rinsing

- High-pressure water plus slurry for spot decontamination 
$-20+80$ Mesh Frit 411

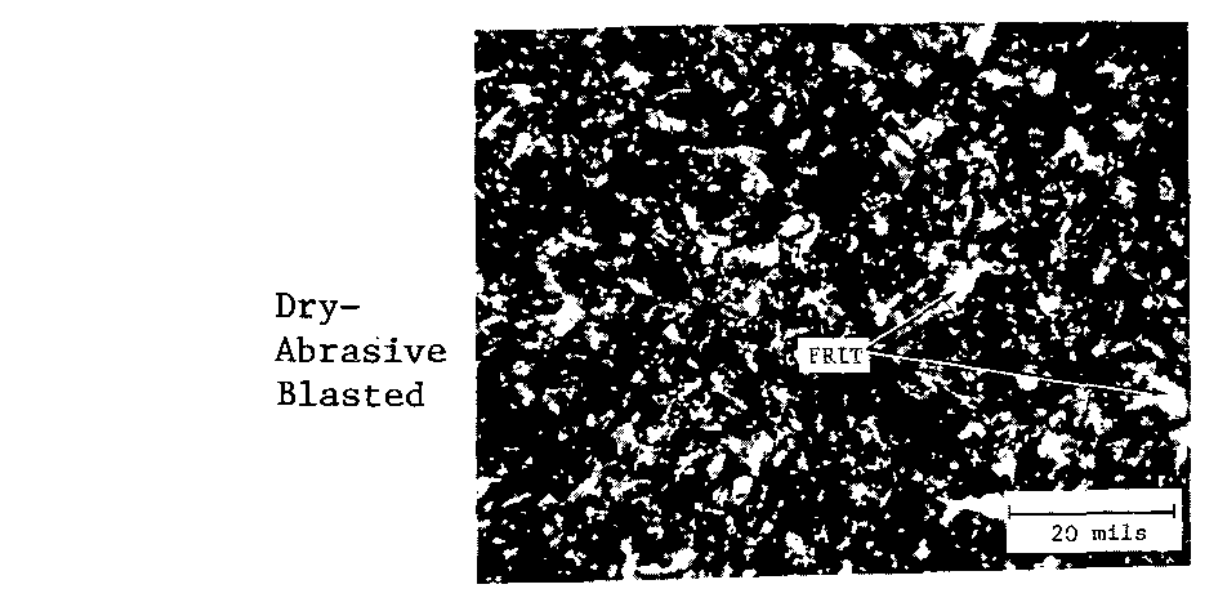

$\sim 10$ in. ${ }^{3}$ of Frit/Canister

N
-80 Mesh Frit 411
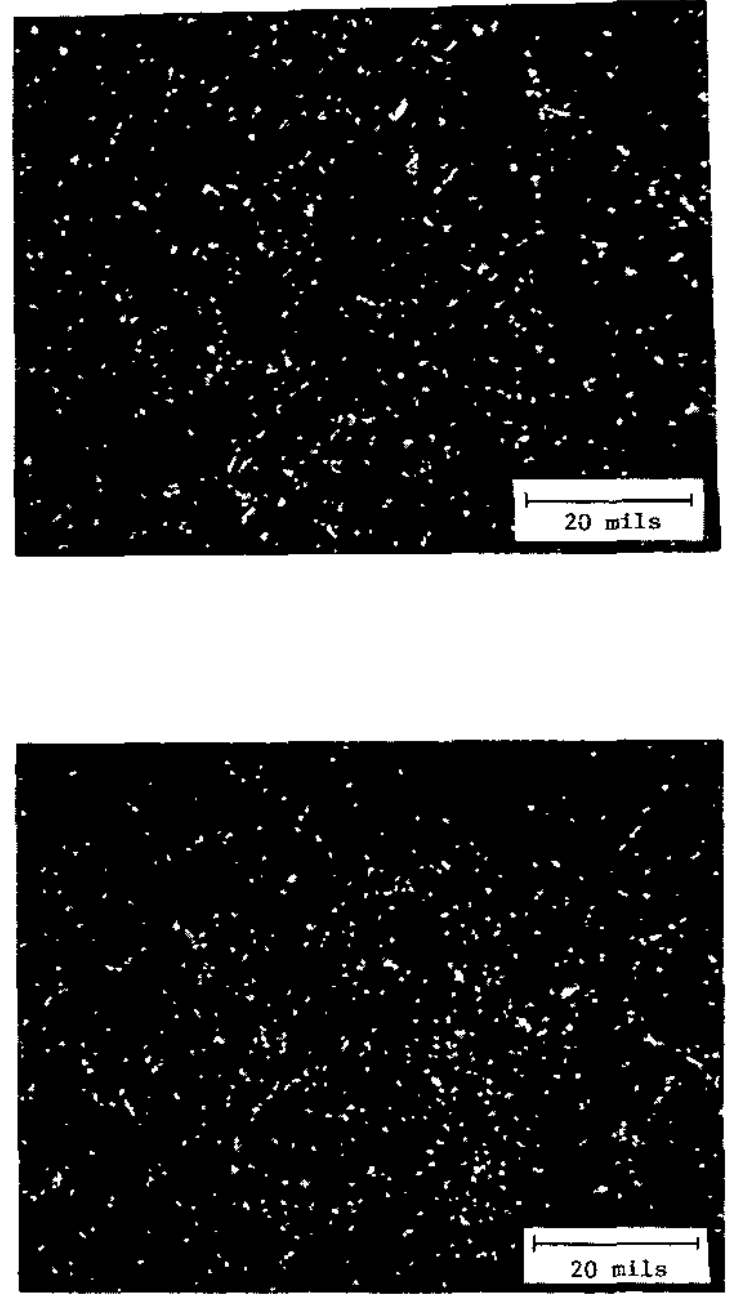

FIGURE 5. Frit Observed in Surface Topography 
This process was chosen by comparing the advantages and disadvantages of all abrasive blasting processes investigated (Table 7). All processes were compared from test data with -80 mesh frit. All investigated processes with -80 mesh frit produced a better surface finish with less frit observed in the topography of the surface.

- Dry Abrasive

Blasting with dry abrasive is the easiest technique to apply because no water is used, and less equipment is required. This technique has the disadvantage, however, especially with the -80 mesh frit, of covering the surface being decontaminated plus the inside of the process vessel and associated ductwork with dust. This dust is not sufficiently removed by blasting the surface with compressed air to 1) produce the cleanest surface possible or 2) allow a good chance for contact maintenance of equipment. There is also the possible problem of filtering the small particles of the -80 mesh from the exhaust air.

- Slurry

Water is used for the slurry-abrasive blasting techniques If waste glass is produced in a dry-fed melter, this water would have to be removed. If a slurry-fed melter is used (the present reference process), the water will not have to be removed. There is no dust in a wet system, and mist is not expected to be a problem. ${ }^{5}$ Wet techniques produce cleaner surfaces than dry techniques and allow a good chance for contact maintenance of equipment by flushing out the system with water.

- High-Pressure Water Plus Frit

This technique is more powerful and better than slurryabrasive blasting for removing adherent glass. Less water and frit are used for high-pressure plus frit blasting than with slurry. This technique is ideally suited for spot decontamination.

\section{Conceptual Design}

Equipment necessary for decontaminating canisters with abrasive blasting techniques will be located in both the service and cell areas of the processing facility (Figure 6).

The main piece of decontamination equipment will be the decontamination chamber. A canister to be decontaminated will be put inside the chamber, and the top of the chamber will be closed. 
TABLE 7

Advantages and Disadvantages of Abrasive Blasting Processea*

Process

Dry-Abrasive

Bl asting

Slurry-

Abrasive

Blast ing

High-Pressure

Water Plus Frit-

Abrasive Blasting
Advantages

No water disposal

Less equiprent required

No dusting

Cleanet surfaces

- Less loose frit on surface

- Less frit observed in surface topography

Better chance of decont aminat ing equipment by flushing for contact naintenance

No dusting

Cleaner surfaces

- Less loose frit on surface

- Less frit observed in surface topography

Most powerful rechnique for removing adherent glass

High-pressure water needed for rinse.

Better chance of decont aminating equipment by flushing

for contact waintenance

* All processes are compared with only -80 mesh frit.
Disadvant ages

Dusting

Surfaces not as clean

- mure luose frit on surface

- more frit observed in surface topographv

Conveving dry frit oure difficult

Litcle chance of decontaminating equidment bv bluwing for contact maintenance

Possible oroblems filtering frit from exhause air

Water disposal

Wear un feed system

More equipment required
Wator disposal

Uses more water than slurry

Wear on feed syotem

vore equipment required 
CELL AREA

SERVICE AREA

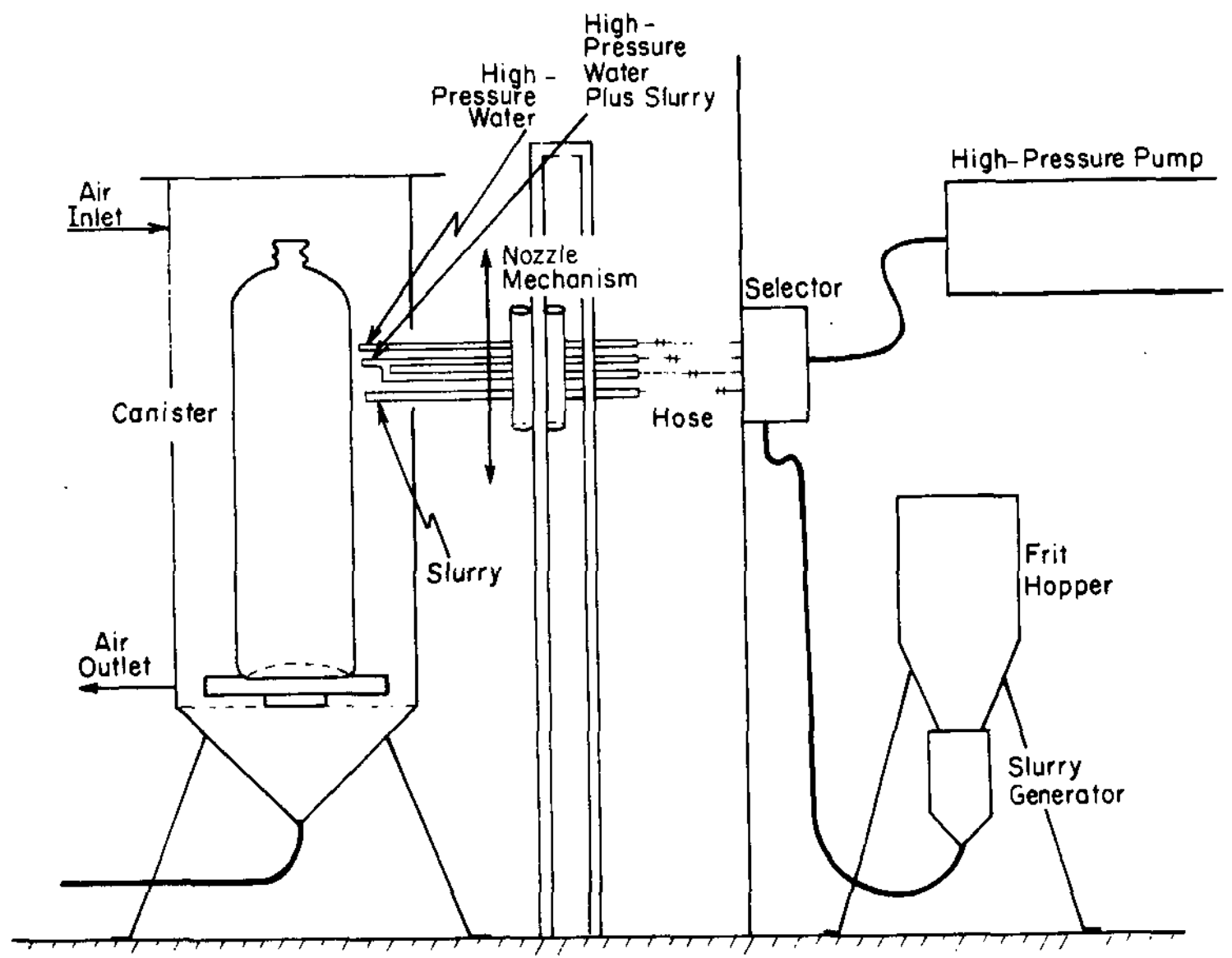

FIGURE 6. Concept of Equipment for Decontamination With Abrasive Blasting 
Inside the chamber, the canister can be picked up by the top flange and rotated. An array of nozzles on a single carrier can be moved vertically the length of the rotating canister. Slurry, high-pressure water, or high-pressure water plus slurry from the nozzles will be able to contact every part of the canister as it is rotated. To clean the part of the ftange under the grasping device on the canister, the canister will be lowered to the floor of the chamber, and the grasping device will be reoriented. The waste from the decontamination process will have to be removed from the chamber; the excess water will have to be separated; and finally, the frit plus the stainless steel oxides will have to be combined with the feed which goes to the glass melter. Before the top of the chamber can be opened and a decontaminated canister can be removed, air should circulate through the chamber to remove all airborne mist and to dry the canister. Air should also be exhausted through filters that can be backwashed periodically for cleaning. After a decontaminated canister has been removed from the chamber, it is moved to a monitoring station where its surface is surveyed for transferrable radioactive contamination. The orientation of the canister in the monitoring station must be referenced to an orientation mark so that it can be returned to the decontamination chamber for spot decontamination of a specific area.

The decontamination chamber will be supplied high-pressure water and slurry from equipment in the service area. The equipment in the service area does not become contaminated; therefore, maintenance of this equipment is easy. 


\section{ACRNOWLEDGEMENTS}

The author would like to express his appreciation to the following people:

- R. R. Herries and R. S. Ondrejcin, E. I. du Pont de Nemours \& Co., Savannah River Plant, Aiken, South Carolina.

- J. R. Cherney and P. L. Heinemann, E. I. du Pont de Nemours and Co., Wilmington, Delaware.

- Ronald L. Brown, Brown. Finishing Equipment Company, Statesville, North Carolina.

- Michael E. Mead, President; Stan Finn, Design Engineer; and Claes Bergstrom, Manager of Research and Development of VacuBlast Corporation, Belmont, California.

- George Rankin, President, and James F. Spuhler, Technical Director, Aqua-Dyne Engineering, Incorporated, Houston, Texas.

- Thomas F. McCarthy, Industry Sales Regional Manager and John Lawson and Ken Sparling, Senior Specialists, Manufacturing Research, Lockheed-Cal ifornia Company, Burbank, California. 


\section{REFERENCES}

1. "Standard and Recommended Practice for Cleaning and Descaling Stainless Steel Parts, Equipment, and Systems." 1980 Annual Book of ASTM Standards. Part 3, ANSI/ASTM A 380-78, American Society for Testing and Materials, Philadelphia, PA (1980).

2. Decontamination of Nuclear Reactors and Equipment. Ed., Ayres, J. A., Ronald Press Company, New York, NY (1970).

3. "General Requirements for Flat-Rolled Stainless and HeatResisting Steel Plate, Sheet and Strip." 1980 Annual Book of ASTM Standards. Part 3, ANSI/ASTM A 380-79, American Society for Testing and Materials, Philadelphia, PA (1980).

4. C. Fong. "Taking the Sand Out of Blasting." Am. Mach., p. 67 (October 14, 1974).

5. M. Laser. Kernforschungsanlage Julich Cmbh, Postfach 1913, D-5170 Julich, Federal Republic of Germany, personal communication (1980). 